\title{
Economic Rational of Current Demonetization Practice of Ethiopia and Its Challenges
}

\author{
Yeshiwas Ewinetu Tegegne (MSc in development Economics) \\ College of Business and Economics, Economics department \\ Debre Markos, University Ethiopia
}

\begin{abstract}
Governments in developing country like Ethiopia demonetize its currency for economic and political reasons. Hence, the main objectives of this paper is to assess the economic rational of demonetization in Ethiopia and its existing challenges. The study employed secondary data obtained from IMF, FAO, ITO and NBE from 2006 to 2020 and observed facts. The data is presented in line graph and bar graph and also analyzed by using descriptive statistics. The finding of this paper reveled that running inflation, increase in public debt, prevalence of high corruption, high budget deficit, low rate of saving and low tax ratio are some of important rational to apply currency demonetization in Ethiopia. It is also found that the success of meeting its stated objectives in Ethiopia is challenged by presence of predatory institutions, existing political unrest, desert locust outbreak, internal displacement and rising trend Covid-19 pandemic and weak implementation capacity of government officials and experts. This paper advice that government should strengthen implementation capacity of government officials, ensuring accountability and transparency among executive bodies and experts and finally the government due attention in building strong developmental institutions before applying financial move like demonetization for the future.
\end{abstract}

Keywords: Demonetization, economic rationales, challenges, Ethiopia.

DOI: $10.7176 / \mathrm{JESD} / 12-7-05$

Publication date: April $30^{\text {th }} 2021$

\section{Introduction}

Demonetization means substitutes one country national currency in whole or in part with a new form of money. It is also an economic process of wiping out old currency by introducing a new one. Alternatively, it is an act of denying old banknotes of their legal tender status (Sharif Mohd, 2016). Governments in least developing countries mostly demonetize their currencies for several numerous economic and political reasons why a country demonetizes its currency; the several reasons are preventing hyper inflation, to combated criminal activities like counter faulting, corruption and terrorism; to promote the cashless transactions, to push informal economic activity into more transparency, to implement a new currency standard across countries and cracking down on black money. The process of demonetization starts from making the old currency discontinued and pulled from circulation,then after Peoples are given time to exchange and finally takeover legal tender status of old currency. Ethiopia like other countries this year implementing demonetization of currency due to some economic and political reasons hence, the main objectives of this paper is to assess the economic rationales of currency demonetarization and its show the observed challenges which hider its success.

\section{Method}

This paper uses secondary time serious data starting from 2006 to 2020 obtained from International monetary fund (IMF): World out looks, Food and Agriculture Organization (FAO), National Bank of Ethiopia, Ethiopian Herald News paper and Journal articles. The methods of data presentation are mostly line graph and bar graph and the analysis is fully descriptive statistics and synthesis.

\section{Empirical Litterateur Review}

In this section of the papers, the reviewer try to put summer result of nine countries of the world, their major objectives of demonetization and major results of demonetarization the countries are presented. 


\begin{tabular}{|c|c|c|}
\hline Country & Objective & Result of Demonetization \\
\hline 1)Nigeria (1982) & $\begin{array}{l}\text { To boost the economy and reduce } \\
\text { debt }\end{array}$ & $\begin{array}{l}\text { The debt-ridden, Inflation hit and the economy } \\
\text { collapsed. }\end{array}$ \\
\hline 2)Ghana(1982) & $\begin{array}{l}\text { To reduce tax evasion and Rise } \\
\text { liquidity and smooth running of } \\
\text { economy. }\end{array}$ & $\begin{array}{l}\text { Peoples Support the black market and People } \\
\text { invest in physical asset finally the economy } \\
\text { becomes weak, corruption and ethnic war and } \\
\text { Downfall of the dictator. }\end{array}$ \\
\hline 4) Zimbabwe( 2015) & $\begin{array}{l}\text { To combat hyper inflation by } \\
\text { Appling Mute- currency system } \\
\text { like; U.S. dollar, British pond, } \\
\text { Botswana pula and South African } \\
\text { rand. }\end{array}$ & $\begin{array}{l}\text { Biggest benefit to micro and SMEs, better value for } \\
\text { money and control inflation }\end{array}$ \\
\hline $\begin{array}{l}\text { 5) North Korea } \\
\text { (2010) }\end{array}$ & $\begin{array}{l}\text { To counter attack the black } \\
\text { market. }\end{array}$ & $\begin{array}{l}\text { Acute shortage of cash, Shortage of supplies and } \\
\text { left people with no food and shelter and finally, } \\
\text { many people's starved to death }\end{array}$ \\
\hline $\begin{array}{l}\text { 6) Soviet union } \\
\text { (1991) }\end{array}$ & To counter the black market & $\begin{array}{l}\text { Coup attempt which brought down leaders from } \\
\text { their authority and led to Soviet breakup. }\end{array}$ \\
\hline 7) Australia(1996) & $\begin{array}{l}\text { To Curb black money and } \\
\text { Improve the security features by } \\
\text { introducing polymer-based note }\end{array}$ & $\begin{array}{l}\text { No any side effect on the economy but only makes } \\
\text { business friendly country. }\end{array}$ \\
\hline 8) India (2016) & $\begin{array}{l}\text { To curbing black money, reduce } \\
\text { terror funding, Stopping the use } \\
\text { of fake currency, Flushing out tax } \\
\text { cheats and to move toward the } \\
\text { cashless society. }\end{array}$ & $\begin{array}{l}\text { Electronic transactions are up Bank deposit } \\
\text { increases, government control transactions, Stock } \\
\text { market crash, transportation disruption, drop in } \\
\text { industrial output, Shortage of cash } \\
\text { Job loss unorganized in formal sector and in small } \\
\text { enterprises and Low Economic growth rate }\end{array}$ \\
\hline $\begin{array}{l}\text { 9) European } \\
\text { Union( 2002) }\end{array}$ & $\begin{array}{l}\text { To assure a smooth transaction } \\
\text { among the members country. } \\
\text { They introduce Euro as every day } \\
\text { currency for EU through } \\
\text { demonetizes mark, frac, and lira. }\end{array}$ & Smooth transition were realized \\
\hline
\end{tabular}

Source: Own construction from literatures reviewed

\section{Demonetization Practice in Ethiopia}

In 1932 the state bank of Ethiopia issued a new currency of note and coin stay till1935. From 1935-1941the Italian attempt to have lira as the only legal tender but failed because framers refuse to sell its product with lira rather Marian Theresa dollar. In April 1941 Ethiopia define East Africa shilling, Egyptian pound, Indian rupees, British sterling and Yemeni rupees as legal tender. In June 1945 national legal tender currency was issues by and MTD was immediately demonetized. The creation of national currency should be viewed us one of the crowing achievements of the imperial government in Ethiopia (Befekadu Degefa, 1993).

In 2006 Ethiopian government demonetized its currency and introduced 1 birr, 5 birr, 10 birr, 50 birr and 100 birr denomination were used as means of payment and the government of Ethiopia has announced the demonetization of its currency in 2020 with the believe that newly introduced banknotes will help the country; to end hoarding, counterfeiting, curb corruption and illicit trade, reduce foreign debt and to reduce budget deficit etc by introducing a new banknotes for three denominations and introduced one new denomination of which the 200 bill is the highest bill and also the government has a plan of current five birr note will be changed to coin. The 10 birr, 50 birr and 100 birr denominations have got a complete new feature including colour changes. The features of 10 birr denomination has now a 100 birr look in terms of colure and bears a picture from the old 5 birr notes a farmer collecting coffee. And also the new fifty birr note does not have change in terms of colour. The picture represents Ethiopia's ambition to transform agriculture in the country. The new 100 birr notes has the old 5 birr notes look with a picture of Ethiopia's main tourist attractions sites. The government also introduced a new 200 denomination. This banknote looks much like the 100 birr note which was in use before the coming of Tigray People's Liberation Front (TPLF) to power in 1991. And it bears a symbol of peace a dove with palm leaves.

During the course of demonetization 3.7 billion birr is spent for printing the new banknotes and 2.9 billion birr new bank notes were ready for distribution initially till know 67 billion were distributed. The amount of cash withdrawal and cash stash for individuals and businesses to 1.5 million birr only above this amount it will be confiscated except businesses with a huge cash transaction like gas stations, among other businesses. Peoples are 
allowed Birr 5,000 direct convert new money in cash and if more than 5,000 open account to convert the new money. During the three-month window, both the new and old notes will remain in circulation.

The notes of 100, 50, and 10 denominations will stand canceled after three months, as they have been replaced with new notes. The cash withdrawal from banks should also not exceed 100,000 birr's. The result of demonetization of currency increased the amount of bank deposits (13.5 billion Birr) and 580 thousand Ethiopians opened new bank account. Furthermore, the Ethiopia governments held over 7.6 million birr black money and finally in the way of achieve the political objectives of capturing the military joint (pervious TPLF) leaders. Actually, assessing the economic and political effects of demonetization is going concerns of researchers but the main purpose of this paper is to look in to the possible empirical facts that pushed the government to take this bold financial move and highlight the challenges that hinder the effectiveness of demonetarization in Ethiopia in year 2020.

\subsection{Immediate Reasons of Demonetization of Currency in Ethiopia}

It is most widely believed that TPLF leaders and individuals linked to former TPLF leaders have stashed billions of Ethiopian birr illegally which leads the political turmoil in Ethiopia for the last five year to reach at its peak and other peoples are live in panic and they tend to withdraw their savings and stash it out of circulation which in turn leads to existence of Bank run in Ethiopia. Additionally, the expansion of the COVID-19 pandemic raised the withdrawal of cash reserve from banks. Furthermore, the Ethiopian Bankers Association (EBA) has reported that over 113 Billion birr is out of the formal banking system (Wossenseged Assefa, 2020).

\subsection{Possible Economic Reasons of Demonetization of Currency in Ethiopia \\ 4.2.1 Low saving as part of Gross Domestic product}

Ethiopia's economy experienced strong, extensive economics growth averaging more than $9.8 \%$ a year from 2008/09 to 2018/19, Ethiopia's. However the trend of still saving to GDP ratio is still low compare to Singapore $(69.70 \%)$ as shown in figure 2.

Figure 1: The trend of savings to Gross domestic product of Ethiopia from 2006-2020.

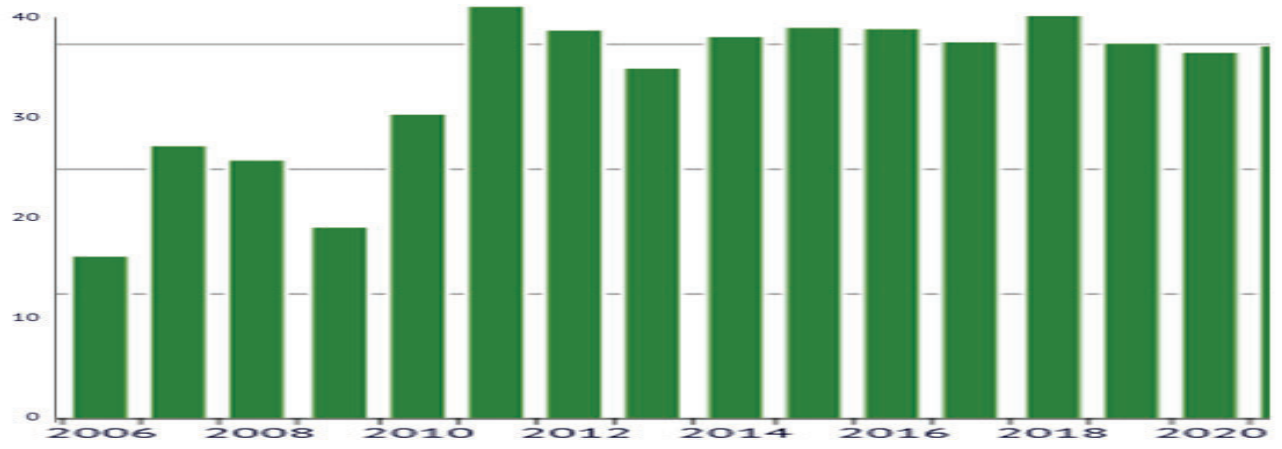

Source: International monetary Fund Data Base (Accessed January, 2020).

\subsubsection{Running stage of Inflation for the last decades}

Classical economists argued that there is a negative relationship between economic growth and inflation implicitly. Inflation reduce saving and investment and their by affecting capital accumulation. Empirical evidence double digit inflation rate can lower the purchasing power of peoples and increase cost of livings and their by reduce growth of real gross domestic products of a given country but the target rate of inflation to accelerate real GDP varies from country to country or might not existence of threshold effect (Bruno, M., \& Easterly, W.(1998); Khan, M. S., Senhadji, A., \& Smith, B. D. (2001); Ashagrie Demile,(2015) etc. For the last 14 years the inflation rate is on average double digit rise cost of living in Ethiopia like cost food, cloth and shelter as shown in figure 1 below .

Figure 2: The trend of inflation rate in Ethiopia from 2006-2020

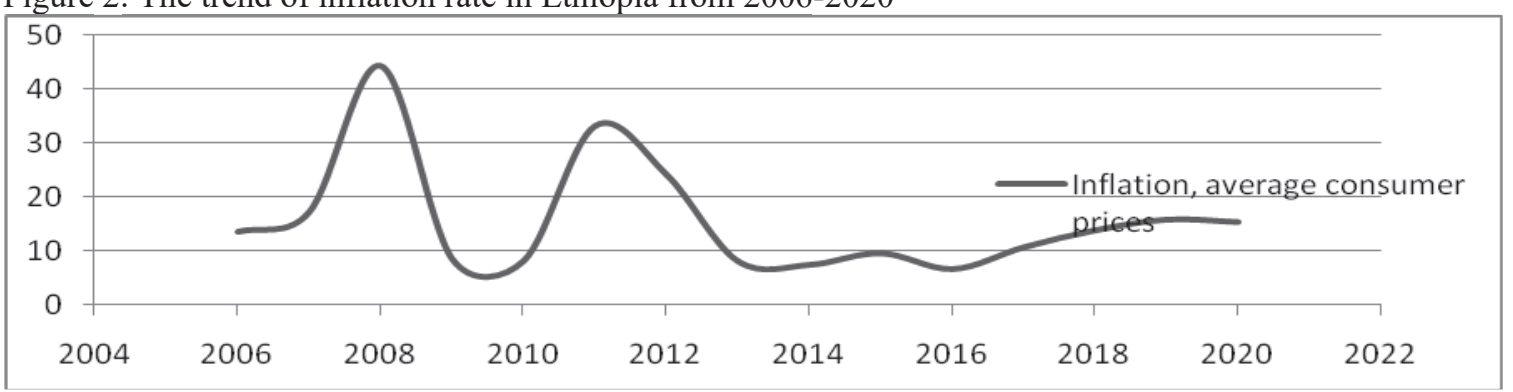

Source: International monetary Fund Data Base (Accessed January 20, 2020). 


\subsubsection{The prevalence High Corruption in Ethiopia for the Last decades}

Governments will apply demonetization of currency to curb the problem of corruption and to make handy cap the terrorist support funds. The International transparent organ data showed that the corruption index of Ethiopia is experiencing an increasing trend as depicted in figure 3 below.

Figure 3: The trend of corruption index in Ethiopia from 2006-2020.

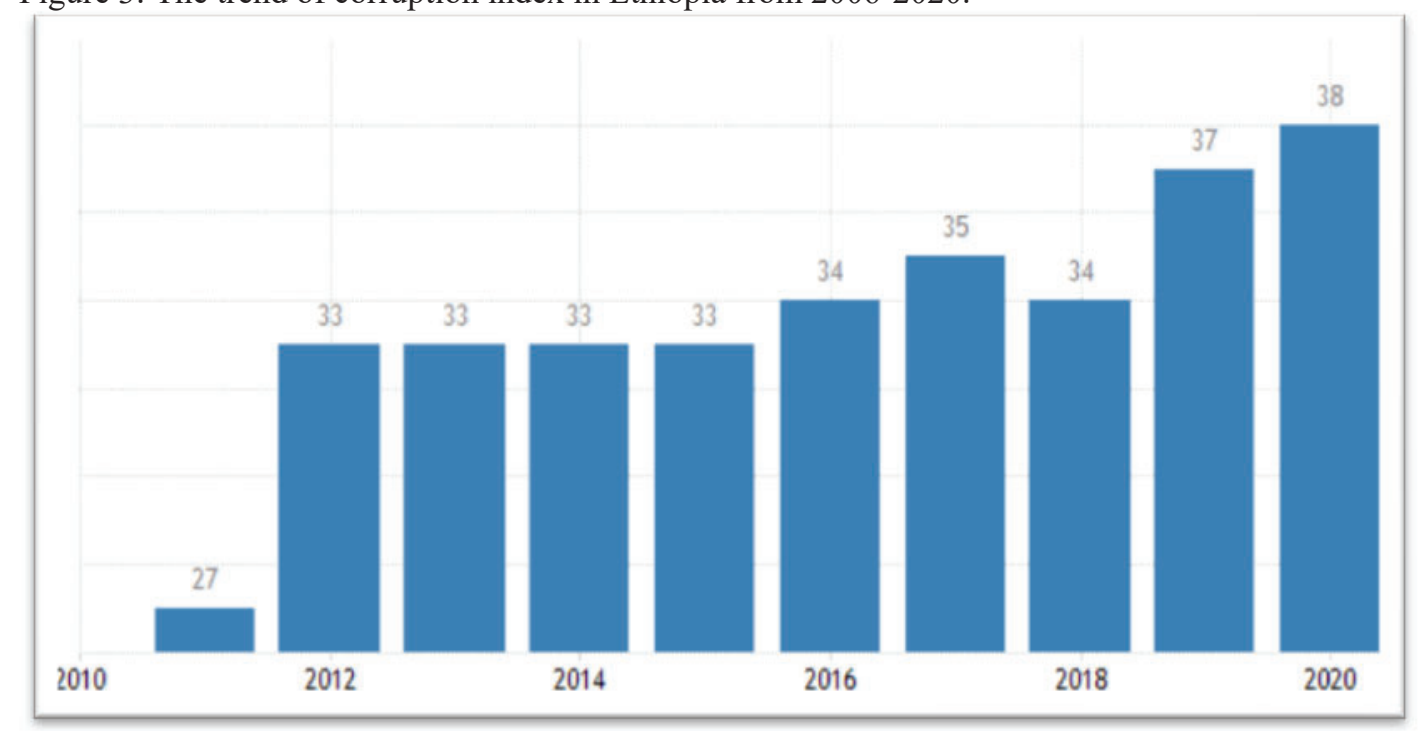

Source Transparency International Organ 2020(Accessed, January 20, 2021)

4.2.4 An Increase in Trend of Budget Deficit in Ethiopia for the last decades

When a country faces the problem of budget deficit, printing of new currency will applied as remedial measure. As shown in figure 4 below the trend of budget deficit shows an increasing trend between the years 2006 to 2020 . Figure 4: Trend of budget deficit in Ethiopia from 2006-2020.

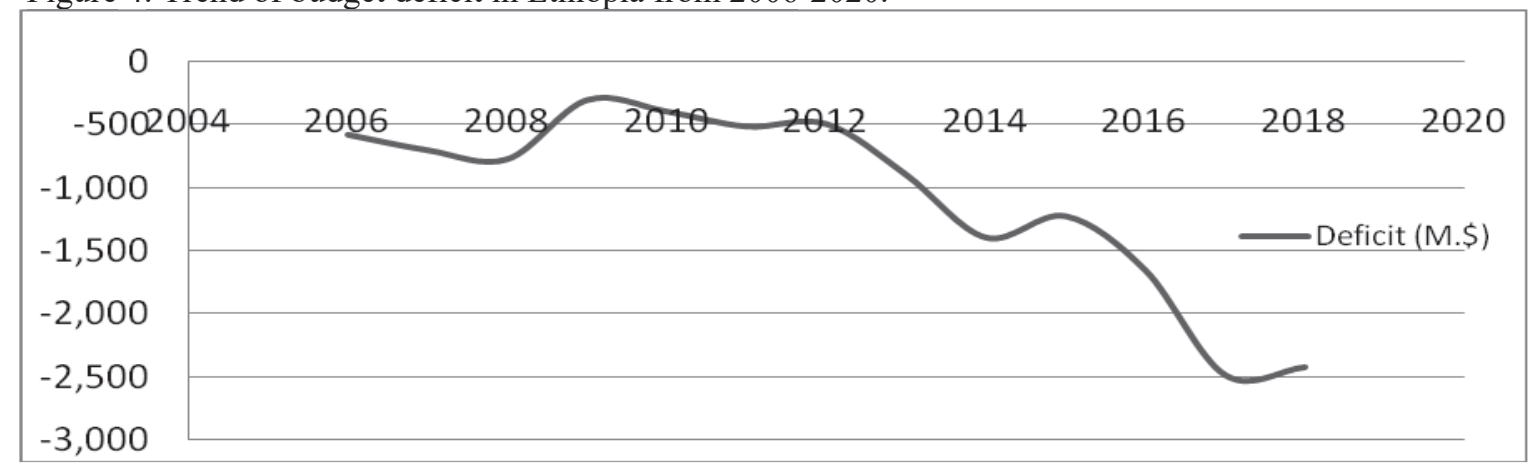

Source: International, monetary Fund Data base 2020(Accessed on January 10, 2020).

\subsubsection{Low Capacity of Tax Collection in Ethiopia}

When the amount of revenue collected through tax in danger due to smuggling, tax avoidance black market and tax evasion prevailed in a given country demonetarization of domestic currency would be applied. For the year 2006-2020 the amount of tax ration or total tax revenue to gross domestic product of Ethiopia is on average less than ten percent of GDP which is less than Colin Clark critical limit ( 25 percent revenue per GDP) as shown in Table 5 below.

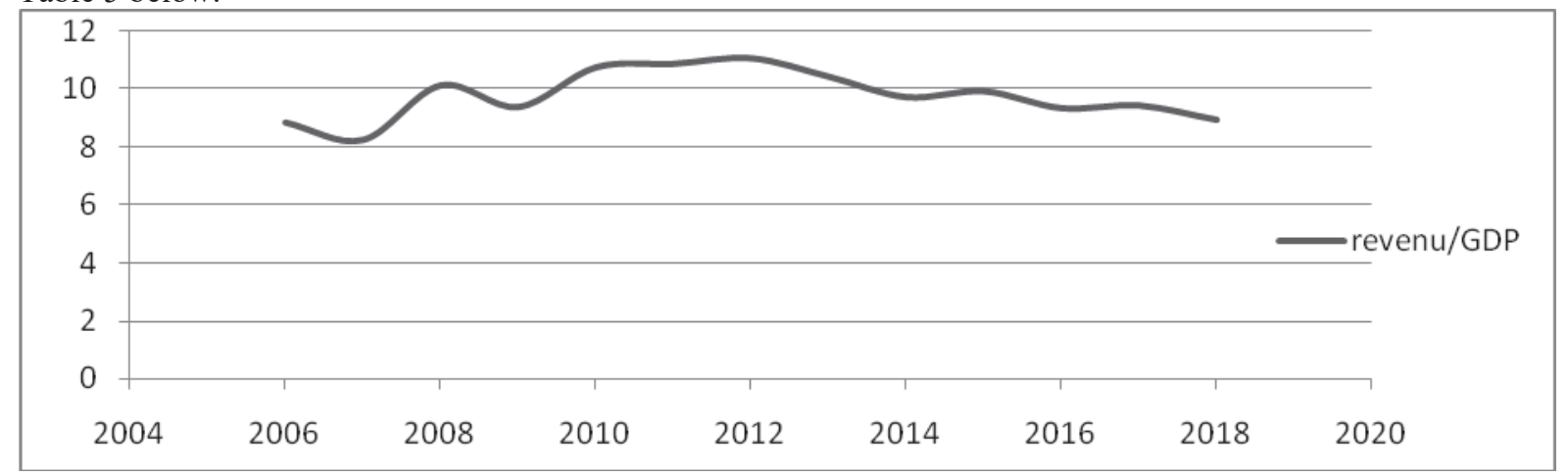

Source: International, monetary Fund; World Economic Outlook, 2020 


\subsubsection{Public debt is going up in Ethiopia for the last decades}

Economics literature shows that when public debt as part of GDP is between 64 up to 70 percent, it will slow down a given country economy 1.70 percent to 2 percent down. The trend of public debt as part of GDP is on average high as shown figure 6 below.

Figure 6: Trend of public debt to Gross domestic product in Ethiopia

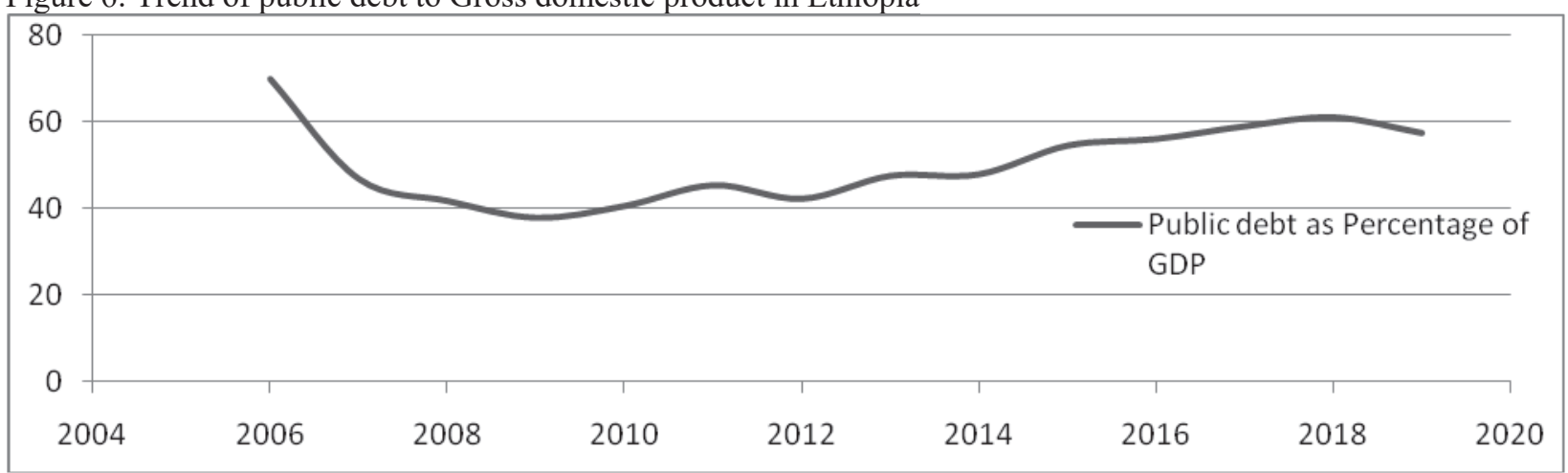

Source: Source: International, monetary Fund; World Economic Outlook, 2020.

4.2.6 Fasts economic growth had started slow

Ethiopia is the fastest growing economy in sub -Sahara Africa however between the years 2006-2020; the economic growth rate of Ethiopia had shown slower as depicted in figure 7 below so to boot the economy demonetarization of currency can be possibly implemented.

Figure 7: Trend of Economic growth rate in Ethiopia between 2006-2020.

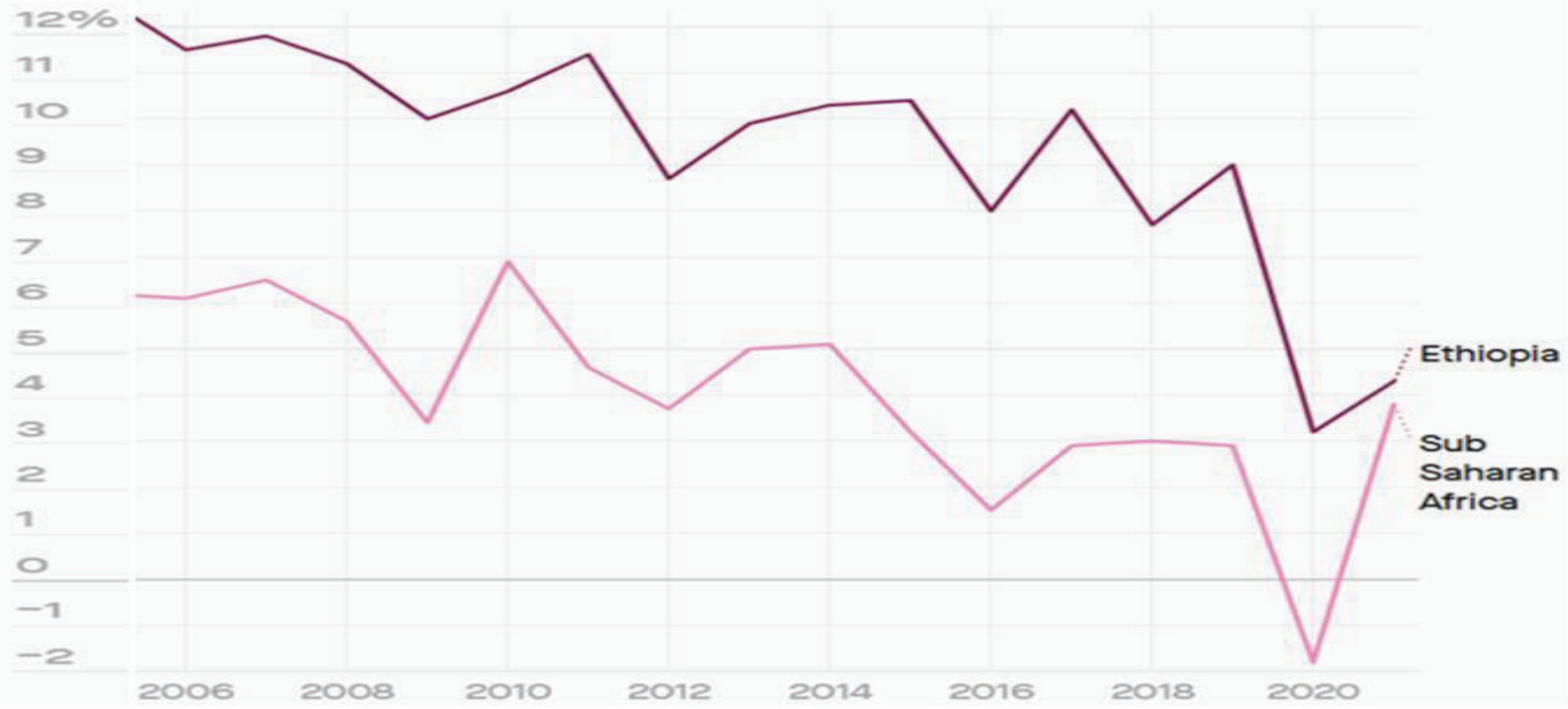

Source: Source: International, monetary Fund; World Economic Outlook, 2020.

\section{Challenges of Current Demonetization Practice in Ethiopia}

The success of demonetarization is matter of absence of predatory institution and additional handicaps. However, in Ethiopia still there exist black market, internal displacement, race based conflict, tax avoidance, tax evasion and smuggling activity are becoming our day to day practice and it might breed other new corrupt groups and institutions while drying up the old oligarchs. Moreover, the worst desert locust outbreak in Ethiopia is additional challenges that affect the success of demonetarization of currency in achieving economic objectives of Ethiopia. Reports shows that swarm of desert locusts have damaged over 200,000 hectares of cropland in Ethiopia. Rural household's loss of over 356,000 tons of grain like sorghum, maize, wheat and Teff. Ethiopia seeks an aid to help 5.6 million people in need of food aid (FAO, 2020).

Furthermore, political unrest and war and internal displacement on Amahara race based assault particularly. International Organization for Migration (IOM) reports show that 1.8 million internally displaced persons (IDPs).Rank (11/173 countries). The causes of internal displacement are conflict $(1,233,557)$, drought $(351,062)$, Seasonal floods $(104,696)$, and flash floods $(50,093)$ respectively (IOM, 2020).

Finally, the sustainability of Coid-19 pandemic will reduce the real gross domestic product growth of Ethiopia adversely. It is expected to reduce Real GDP growth to 2.6 percent from 7.2 percent with the worst case scenario and 3.6 percent with baseline scenario as shown in figure 8 . 
Figure 8: The negative impact of Covid-19 on real gross domestic product growth of Ethiopia

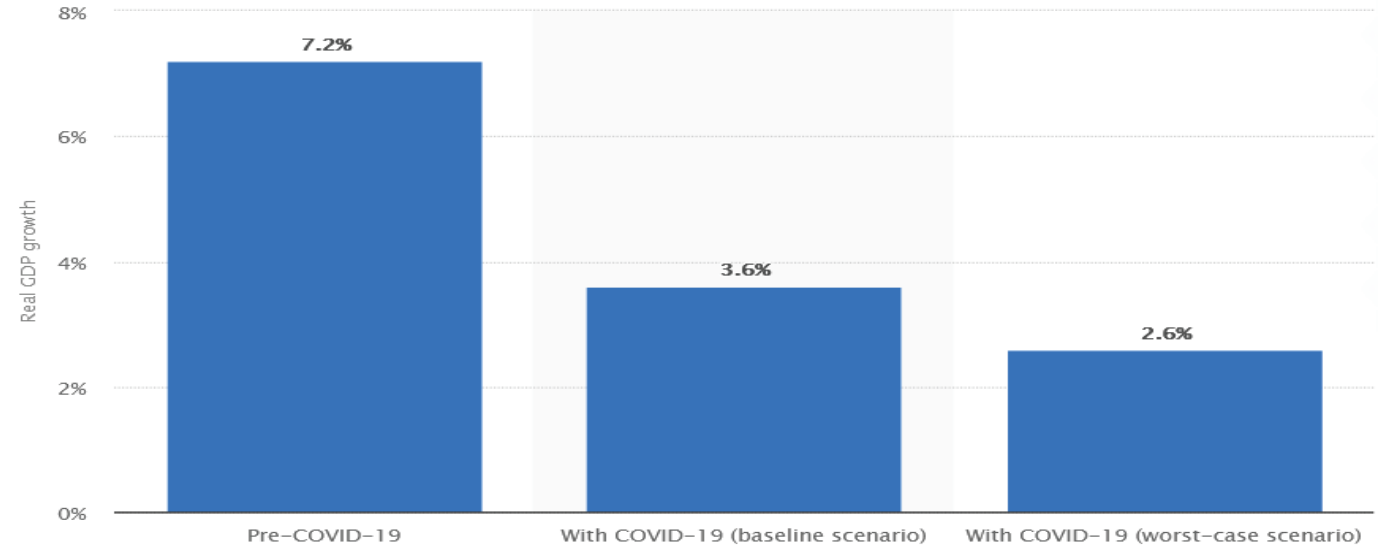

Source: International monetary Fund; World Economic Outlook, 2020

\section{Conclusion}

Demonetization is important for Ethiopia to end hoarding, counterfeiting, curb corruption and illicit trade, reduce foreign debt, increase national saving and to reduce budget deficit and to meet political objectives. However, the success of meeting its stated objectives is challenged by presence of predatory institutions, exiting political unrest, desert locust outbreak, internal displacement and implementation capacity of leaders and Covid-19 pandemic. This paper advice that the government should built developmental institutions and improves implementation capacity of leaders before applying financial move like demonetization for the future.

\section{REFERENCE}

Ashagrie Demile (2015). "Inflation Growth Nexus in Ethiopia: Evidence from Threshold Auto Regressive Model". Ethiopian Journal of Economics. Vol. XXIV No 1, PP 1-30.

Goriparthi, R. K., \& Tiwari, P. (2017). Demonetization in India an era for digital payments. Splint International Journal of Professionals, 4(1), 40.

Balaji, K. C., \& Balaji, K. (2017). A study on demonetization and its impact on cashless transactions. International Journal of Advanced Scientific Research \& Development, 4(3), 58-64.

Kulkarni, K. G., \& Tapas, P. (2017). Demonetization comparatistics: India and others. SCMS Journal of Indian Management, 14(1), 5-13.

Choudhary, U. (2021). The impact of demonetization on Indian economy.

Chowdhury, M. H., \& Hosain, S. (2018). Demonetization policy: The Indian debate. Asian Journal of Research, (2), 7-12.

Hagos, M. K., \& Asfaw, M. (2014). Financial Regulation and Supervision in Ethiopia. Journal of Economics and Sustainable Development,5(17).

Wossenseged Assefa(2020). Ethiopia's Demonetization Possible Causes and Effects. Ethiopia Herald News paper.

Khan, M. S., Senhadji, A., \& Smith, B. D. (2001). Inflation and financial depth. Bruno, M., \& Easterly, W. (1998). Inflation crises and long-run growth. Journal of Monetary economics, 41(1), 3-26.

International monetary Fund: World outlook (2020).

Report of International Organization for Migration (2020).

International Transparent organ (2020).

Befikadu Degefe(1993). The Making of the Ethiopian National Currency 1941-45. Journal of Ethiopian Studies, 26(2), 23-51. Stable URL: https://www.jstor.org/stable/41966019 .

\section{Web pages}

https://afr-corp-media-prod.s3-eu-west-1.amazonaws.com/afrexim/Africas-2020-Growth-Prospects.pdf 